\title{
Cultivation of gerbera irrigated with treated domestic effluents ${ }^{1}$
}

\author{
Lisânea M. 0. D amasceno ${ }^{2}$, Aderson S. de Andrade Júnior ${ }^{3}$, Hans R. G heyi ${ }^{4}$, Valdenir Q. Ribeiro ${ }^{3}$ \& N ildo da S. Dias ${ }^{5}$
}

\begin{abstract}
This paper evaluates the nutritional impact on growth, production and quality variables of gerbera crop when fertigated with treated domestic effluents. An experiment was carried out in greenhouse at the Embrapa Meio-N orte in Teresina, in the State of Piauí, Brazil, from July to 0 ctober 2007. A completely randomized experimental design with five treatments and five replications was adopted. The treatments investigated were $\mathrm{T}_{1}-100 \%$ of water and nutritional requirements of crop were met with chemical fertigation $\left(\mathrm{N} \mathrm{e} \mathrm{K}_{2} \mathrm{O}\right) ; \mathrm{T}_{2}-25 \%$ volume of water through fertigation and $75 \%$ treated wastewater effluents (TWE); $\mathrm{T}_{3}: 50 \%$ volume of water through fertigation and $50 \% \mathrm{TWE}_{\mathrm{T}} \mathrm{T}_{4}: 75 \%$ volume of water with fertigation and $25 \%$ TWE; and $\mathrm{T}_{5}-100 \%$ volume of water supplied through TW E. Leaf growth and plant development were favored by the application of 50\% fertigation and $50 \% \mathrm{TWE}\left(\mathrm{T}_{3}\right)$. As for commercial requirements, the best results for number of flowers were obtained with $\mathrm{T}_{4}$. However, concerning quality, $\mathrm{T}_{2}$ produced flowers in July and August with longer stems, but in the months of September and 0 ctober, no treatment achieved this standard due to high temperature and low relative humidity of the air in the region.
\end{abstract}

Key words: water reuse, fertigation, Gerbera jamesonii

\section{Cultivo de gérbera irrigada com efluentes domésticos tratados}

\section{RESU MO}

Com o objetivo de avaliar os efeitos nutricionais sob as variáveis de crescimento, produção e qualidade da gérbera (Gerbera jamesonii) quando fertigada com efluentes domésticos tratados conduziu-se um experimento em ambiente protegido na unidade da Embrapa M eio-N orte, em Teresina, PI, utilizando-se delineamento estatístico inteiramente casualizado com cinco tratamentos e cinco repetições. $0 \mathrm{~s}$ tratamentos estudados foram: $\mathrm{T}_{1}-100 \%$ das necessidades hídrica e nutricional das culturas atendidas mediante fertigação $\left(\mathrm{N} \mathrm{e} \mathrm{K}_{2} \mathrm{O}\right) ; \mathrm{T}_{2}-75 \%$ do volume de água residuária tratada (ART) associada a $25 \%$ de fertigação; $T_{3}$ - 50\% de ART associada a $50 \%$ de fertigação; $T_{4}-25 \%$ de ART associada a $75 \%$ de fertigação e $\mathrm{T}_{5}-100 \%$ de ART. 0 crescimento e o desenvolvimento foliar foram favorecidos pelo tratamento de $50 \%$ de fertigação associados a $50 \%$ de $A R T\left(T_{3}\right)$. Quanto às exigências comerciais em número de flores, os melhores resultados foram obtidos em $\mathrm{T}_{4}$, porém, em termos de qualidade, $0 \mathrm{~T}_{2}$ apresentou maior altura das hastes florais, nos meses de julho e agosto; já nos meses de setembro e outubro nenhum tratamento conseguiu alcançar este padrão de qualidade em virtude de altas temperaturas e baixa umidade relativa na região.

Palavras-chave: reúso de água, fertigação, Gerbera jamesonii

\footnotetext{
1 Part of the Master Dissertation of the first author presented at the Universidade Federal de Campina Grande - UFCG

2 Instituto do Meio Ambiente e dos Recursos Hídricos do Distrito Federal - IBRAM. SBS Quadra 2, Edifício Maria Ramos Parente, CEP 70070-928, Brasília - DF. Telephone: (61) 3325-6868. E-mail: lisaneadamasceno@ hotmail.com

3 Embrapa Meio-N orte, Caixa Postal 01, CEP 64006-220, Teresina, PI. Telephone: (86) 3225-1141. E-mail: aderson@cpamn.embrapa.br; valdenir@pamn.embrapa.br

4 UAEA/U FCG, CEP 58429-140, Campina Grande, PB. Telephone: (83) 3310-1056. E-mail: hans@deag.ufcg.edu.br

5 UFERSA, CEP 59600-900, Mossoró, RN. Telephone: (84) 3315-1762. E-mail: nildo@ufersa.edu.br
} 


\section{INTRODUCTION}

Water scarcity in the world is increasing, both in terms of volume and in terms of quality. Irrigated agriculture makes use of over $69 \%$ of all the world's water resources. This can lead to conflicts among the various sectors of society, mainly in the industrial and domestic supply. According to Carr et al. (2004), in spite of water scarcity, population growth, mainly in large cities, has contributed towards an increase of volume of wastewater and consequently that of domestic effluents.

The advantages concerning the use of domestic effluents in agriculture come as a result of economy of water, capacity of recycling of nutrients, economy in fertilizers, control of pollution in water bodies and eutrophycation, as well as the rational use of water reduces sewage discharge into water basins preventing environmental pollution (Bazza, 2002; Carr et al., 2004; Papadopoulos et al., 2004; Janosova et al., 2006; Toze, 2006; Capra \& Scicolone, 2007; Mutengu et al., 2007).

Treated effluents may be used in agriculture as a source of water and nutrients for plants (Bastos, 1999), especially cut flower crops. The management of these crops points out the importance of development of creating new market opportunities as has been observed by various authors (Papadopoulos et al., 2004; Andrade Neto et al., 2005; Bernstein et al., 2006; Cerqueira, 2006; Friedman et al., 2007; Medeiros et al., 2007).

Among the various cut flower species, the gerbera stands out, for its comercial importance and high aggregated product value being in the top 5 most important cut flowers in the Dutch auction (Papadopoulos et al., 2004). The gerbera presents a variety of attractive colors and shapes, achieving the best prices in the market. Various gerbera cultivars have already been placed in the market (INFOAGRO, 2007). In Piauí, the flower industry is still modest, perhaps due to lack of technologies either generated or properly adapted to meet regional demands. Small farmers, however, have already started developing activities in this sector (SEBRAE, 2005).

There is still very little information concerning the use of treated wastewater for irrigation and fertigation; mainly for growing gerbera and/or cut flower species. Darwish et al. (1999) demonstrated that greenhouse crops may be excellent options when associated with the reuse of treated domestic wastewater.

The use of treated domestic wastewater offers the possibility to create new options of cultivation for family agriculture practices in the outskirts of large cities, providing sustainability to this activity with rather positive outcomes with regard to creation of job opportunities and income. The present work focuses on the technical feasibility regarding the use of domestic effluents treated both with and without mineral fertilizer for the growing orange-yellow gerbera of the Rambo variety in Teresina, Piauí, considering the nutritional effects on growth variables, yield and flower quality.

\section{MATERIAL AND METHODS}

The experiment was conducted from $01 / 07 / 2007$ to $31 / 10$ /
2007 in a greenhouse with a 50\% shade screen at the Embrapa Meio-Norte, Teresina, Piaui, located at $05^{\circ} 05^{\prime} 21^{\prime \prime} \mathrm{S}$, $42^{\circ} 48^{\prime \prime} 07 " \mathrm{~W}$ at an altitude of $74 \mathrm{~m}$. According to classification of Köppen, the climate of region is tropical, hot and humid, with rainfall in summer and autumn (Aw), and dry winter (Lima et al., 2002). Table 1 shows the agrometeorological conditions observed during the experimental phase in the greenhouse.

Table 1. M onthly means of the meteorological elements* monitored by the meteorological station in the interior of greenhouse during the experimental periodo

\begin{tabular}{cccccc}
\hline Período & T $\left({ }^{\circ} \mathbf{C}\right)$ & RH $(\%)$ & WS $\left(\mathbf{m ~ s}^{-1}\right)$ & SR $\left(\mathbf{M J} \mathbf{~ m}^{-2}\right)$ & ETo $(\mathbf{m m})$ \\
July & 28.8 & 35.4 & 0.02 & 266.2 & 62.9 \\
August & 28.9 & 26.0 & 0.06 & 294.8 & 71.5 \\
September & 30.6 & 20.6 & 0.07 & 300.5 & 76.2 \\
October & 31.7 & 21.3 & 0.06 & 322.7 & 97.0 \\
\hline
\end{tabular}

* T - air temperature; RH - relative humidity; WS - Wind velocity; SR - solar global radiation and ETo - evapotranspiration of reference

The trial was conducted in a completely random experimental design with five treatments and five replications. The treatments consisted of application of different volumes of treated wastewater effluent (TWE) in combination with chemical fertilizers through fertigation in the form of urea and potassium chloride as follows: $\mathrm{T}_{1}$ - nutritional and water needs of plants met with $100 \%$ fertigation $\left(\mathrm{N}\right.$ and $\left.\mathrm{K}_{2} \mathrm{O}\right)$; $\mathrm{T}_{2}-75 \%$ of the volume of TWE associated with $25 \%$ fertigation; $\mathrm{T}_{3}-50 \%$ of the volume of TWE associated with $50 \%$ of fertigation; $\mathrm{T}_{4}-25 \%$ of volume of TWE associated with $75 \%$ fertigation; and $\mathrm{T}_{5}-100 \%$ of volume of TWE. Each experimental plot consisted of four pots: each containing one plant.

A hole was drilled at the bottom of the pot and a $2 \mathrm{~cm}$ layer of crushed stone was deposited and covered with geotextile mesh, after which a $10 \mathrm{~cm}(4 \mathrm{~kg})$ layer of sandy yellow Latosol (Oxisol) soil collected in an area of the Embrapa Meio-Norte was added. Chemical analysis conducted according to the EMBRAPA (1997) methodology revealed $\mathrm{pH}=5.24$ phosphorus $-21.0 \mathrm{mg} \mathrm{dm}^{-3}$, potassium $=$ $0.32 \mathrm{cmol}_{\mathrm{c}} \mathrm{dm}^{-3}$ and organic matter $=16.68 \mathrm{~g} \mathrm{~kg}^{-1}$. The pots were placed on suspended wooden platform at a height of $0.70 \mathrm{~m}$, measuring $0.80 \mathrm{~m}$ wide and $6 \mathrm{~m}$ long, placed in an area $12 \mathrm{~m}$ wide and $19.5 \mathrm{~m}$ long.

Gerbera seedlings were obtained from the adult plants provided by the Universidade Federal de Campina Grande, initially obtained from BioLab Tecnologia Vegetal Ltda. (Medeiros et al., 2007). Following leaf removal, the plants were left with two adult leaves and one flag young leaf. Treatments were initiated five days after the plants were transplanted to pots.

Drip irrigation system was installed by means of $32 \mathrm{~mm}$ diameter PVC pipes, to which four $16 \mathrm{~mm}$ polyethylene lateral lines were attached (two lines for the application of treated effluents and the two others for chemical fertilizers). Along the lateral lines drippers were installed, and adapters with two or four outlets were also used for fertigation or TWE as treatment. The adapters were connected to micro tubes to 
which stabilizing poles were fitted, and maze drippers were stuck into the soil in the pots.

Two filters, one of sand and another of disc-filter were installed, to prevent possible obstruction of dripper and pole stabelizers by any sediments contained in the water. Two $500 \mathrm{~L}$ tanks were placed in the external part of the greenhouse: one tank to store water from the well, and the other to hold domestic effluents.

After the installation of the irrigation system, the fertilizer injection pump was checked so that the injection rate and pressure could be adjusted to $0.24 \mathrm{MPa}$. Tests to verify the water distribution uniformity (WDU) and the drippers' mean discharge were carried out. The system presented a WDU coefficient of $95.2 \%$, which is considered as excellent (Keller \& Bliesner, 1990) and flow rate varied from 2 to $4 \mathrm{~L} \mathrm{~h}^{-1}$.

From the transplanting until August, irrigation was conducted twice a day, the first for the application of nutrients of mineral supplementation at 08:30 am and the other for the application of water or effluents, at 04:30 pm. From August till the end of the experiment, fertigation was carried out in the morning and in the afternoon due to increase in the crop's nutritional and water demand.

After the application of fertilizers, the system was kept functioning for one minute in order to wash the solution residues in the PVC pipes. When effluents were applied, the same procedure was adopted and in this case only the effluent registers were kept open.

Following recommendations of the BioLab Tecnologia Vegetal and adapted by Medeiros et al. (2007), a nutrient solution containing 200 and $100 \mathrm{mg} \mathrm{L}^{-1}$ of $\mathrm{N}$ and $\mathrm{K}_{2} \mathrm{O}$, respectively, was applied to $\mathrm{T}_{1}$ three times a week during the initial phase (for a period of 30 days after sowing). During the flowering phase the concentration of solution applied was 100 and $200 \mathrm{mg} \mathrm{L}^{-1}$. The application of the nutrient solution was done by means of a fertilizer injecting pump along with irrigation water. Treatments $\mathrm{T}_{2}, \mathrm{~T}_{3}$ and $\mathrm{T}_{4}$, received, respectively, 25,50 and $75 \%$ of this solution; whereas $\mathrm{T}_{5}$ received only TWE, according to the crop water requirement.

The water depth applied was the same for all treatments, calculated on the basis of evapotranspiration (ETo) determined by the Penman-Monteith method and based on the data obtained from the automatic agrometeorological station installed inside the greenhouse. The total volume of water applied was $254.24 \mathrm{~mL}$ per day per plant.

The treated domestic effluents used in the study came from the maturation pond of the Wastewater Treatment Plant ETE LESTE of the Companhia de Água e Esgoto do Piauí S.A. (AGESPISA). Prior to the effluent suction into the PVC reservoir at ETE, a sample was collected for analysis and characterization (Table 2).

Data collection on the growth and development of gerbera was conducted once a week. For the variables size of tillers, young and adult leaves, two plants in each plot were used; whereas, for the data on flower measurement, plants from all plots were used, determining the diameter of capitulum and stem, stem height and number of flowers collected from each pot. For the measurements, a ruler was
Table 2. Physico-chemical composition of treated wastewater during the experimental phase

\begin{tabular}{|c|c|c|c|c|c|}
\hline \multirow{2}{*}{ Parameters* } & \multirow{2}{*}{ Unit } & \multicolumn{4}{|c|}{ Period } \\
\hline & & June & July & Aug & Sept \\
\hline BOD5 & $\mathrm{mg} \mathrm{L}^{-1}$ & 34 & 31 & 33 & 29 \\
\hline $\mathrm{pH}$ & & 7.9 & 7.2 & 7.7 & 7.7 \\
\hline CE & $\mathrm{dS} \mathrm{m}^{-1}$ & 0.75 & 0.43 & 0.80 & 0.92 \\
\hline Ammonia & $\mathrm{mg} \mathrm{L}^{-1}$ & 34 & 37 & 33 & 29 \\
\hline Nitrate & $\mathrm{mg} \mathrm{L}^{-1}$ & 0.18 & 0.39 & 0.21 & 2.00 \\
\hline Chloride ( $\mathrm{Cl}$ ) & $\mathrm{mmol}_{\mathrm{c}} \mathrm{L}^{-1}$ & 1.72 & 1.77 & 1.74 & 1.86 \\
\hline Phosphorus (P) & $\mathrm{mg} \mathrm{L}^{-1}$ & $A$ & 2.00 & $A$ & $A$ \\
\hline Coliforms thermo-electric & $\mathrm{CT} 100 \mathrm{~mL}^{-1}$ & $3.0 \times 10^{4}$ & $2.7 \times 10^{4}$ & $8 \times 10^{4}$ & $7.0 \times 10^{4}$ \\
\hline
\end{tabular}

used to determine the stem height, and a precision caliper $(0.05 \mathrm{~mm})$ was used to measure the diameter of stem and the flower capitulum. The collected flowers were classified, according to the commercial standards recommended by IBRAFLOR (2000). These standards for the extra quality recommend stems over $40 \mathrm{~cm}$ long with diameters of capitulum varying from 10 to $12 \mathrm{~cm}$ and stem diameters more than $0.50 \mathrm{~cm}$.

The data collected were submitted to analysis of variance (F test) and the means were compared by the Student-Newman-Keuls (SNK) test at a probability level of 0.05 using the SAS/STAT procedures (SAS, 1989).

\section{RESULTS AND DISCUSSION}

\section{Leaf growth}

Analysis of variance show no significant effect of treatments on tiller size for measurements made in July and September; however, performance of treatment $\mathrm{T}_{3}$ was superior in relation to $\mathrm{T}_{1}$ and $\mathrm{T}_{5}$ in August, and that of $\mathrm{T}_{5}$ as compared to other treatments in October (Table 3). In the case of the size of young leaves significant effects occurred in July and September at 0.05 level of probability and the differences between $T_{1}$ and $T_{2}$ (July) and between $T_{3}$ and $T_{5}$ in relation to $\mathrm{T}_{1}$ (September) were significant. As for the size of adult leaf the effect of treatment was significant in all months. The difference between $T_{1}$ and $T_{4}$ for July, and $T_{1}$ and $T_{3}$ in relation to $T_{4}$ in August, and between $T_{1}$ and $T_{3}$ in relation to $\mathrm{T}_{5}$ for months of September and October were significant as determined by the SNK test at 0.05 level of probability (Table 3). According to INFOAGRO (2007), the size of gerbera leaf varies considerably, depending on the structure and the cultivar, from 20.0 to $25.5 \mathrm{~cm}$. In this study, the leaf length at all times and under all treatments was over $20 \mathrm{~cm}$ (Table 3), indicating satisfactory crop growth.

Along the time, changes in the number of leaves (tillers + young leaves + adult leaves) were observed in the plants fertigated with wastewater containing nutrients and chemical fertilizers. In the $T_{5}$ treatment, irrigated only with wastewater, the total number of leaves, in all stages, was lower compared to other treatments, in spite of the fact that a gradual development was maintained (Figure 1). Perhaps the essential nutrients, especially nitrogen, contained in treated 
Table 3. Mean length of tiller, size of young and adult leaf during the experimental period under different treatments

\begin{tabular}{|c|c|c|c|c|c|c|c|c|c|c|c|c|}
\hline \multirow{3}{*}{ Treat3 } & \multicolumn{12}{|c|}{ Mean $(\mathrm{cm})^{1,2}$} \\
\hline & \multicolumn{3}{|c|}{ July } & \multicolumn{3}{|c|}{ August } & \multicolumn{3}{|c|}{ September } & \multicolumn{3}{|c|}{ October } \\
\hline & Tiller & Young & Adult & Tiller & Young & Adult & Tiller & Young & Adult & Tiller & Young & Adult \\
\hline F Test & ns & * & $* *$ & $* *$ & ns & $* *$ & ns & $*$ & $*$ & $* *$ & ns & $* *$ \\
\hline $\mathrm{T}_{1}$ & $\begin{array}{c}2.16 \\
(0.226)\end{array}$ & $\begin{array}{l}11.13 a \\
(0.312)\end{array}$ & $\begin{array}{l}22.51 \mathrm{a} \\
(0.364)\end{array}$ & $\begin{array}{l}1.95 \mathrm{c} \\
(0.154)\end{array}$ & $\begin{array}{c}9.58 \\
(0.557)\end{array}$ & $\begin{array}{l}23.05 a \\
(0.294)\end{array}$ & $\begin{array}{c}2.81 \\
(0.251)\end{array}$ & $\begin{array}{l}9.19 \mathrm{~b} \\
(0.385)\end{array}$ & $\begin{array}{l}23.49 a \\
(0.340)\end{array}$ & $\begin{array}{l}3.17 \mathrm{~b} \\
(0.118)\end{array}$ & $\begin{array}{c}10.63 \\
(0.266)\end{array}$ & $\begin{array}{l}24.15 a \\
(0.485)\end{array}$ \\
\hline $\mathrm{T}_{2}$ & $\begin{array}{c}2.22 \\
(0.226)\end{array}$ & $\begin{array}{l}9.69 \mathrm{~b} \\
(0.312)\end{array}$ & $\begin{array}{c}21.50 \mathrm{ab} \\
(0.364)\end{array}$ & $\begin{array}{l}2.59 a b \\
(0.154)\end{array}$ & $\begin{array}{c}11.37 \\
(0.557)\end{array}$ & $\begin{array}{c}22.74 a b \\
(0.294)\end{array}$ & $\begin{array}{c}2.67 \\
(0.224)\end{array}$ & $\begin{array}{c}10.05 a b \\
(0.385)\end{array}$ & $\begin{array}{c}22.77 \mathrm{ab} \\
(0.340)\end{array}$ & $\begin{array}{l}3.05 \mathrm{~b} \\
(0.118)\end{array}$ & $\begin{array}{c}9.99 \\
(0.266)\end{array}$ & $\begin{array}{c}22.25 a b \\
(0.485)\end{array}$ \\
\hline $\mathrm{T}_{3}$ & $\begin{array}{c}2.00 \\
(0.226)\end{array}$ & $\begin{array}{l}11.01 \mathrm{a} \\
(0.312)\end{array}$ & $\begin{array}{c}21.60 a b \\
(0.364)\end{array}$ & $\begin{array}{l}2.99 a \\
(0.154)\end{array}$ & $\begin{array}{c}10.90 \\
(0.557)\end{array}$ & $\begin{array}{l}23.40 a \\
(0.294)\end{array}$ & $\begin{array}{c}2.57 \\
(0.224)\end{array}$ & $\begin{array}{l}10.93 a \\
(0.385)\end{array}$ & $\begin{array}{l}23.13 a \\
(0.340)\end{array}$ & $\begin{array}{l}2.78 \mathrm{~b} \\
(0.118)\end{array}$ & $\begin{array}{c}10.88 \\
(0.266)\end{array}$ & $\begin{array}{l}23.03 a \\
(0.485)\end{array}$ \\
\hline $\mathrm{T}_{4}$ & $\begin{array}{c}2.12 \\
(0.226)\end{array}$ & $\begin{array}{l}10.61 \mathrm{ab} \\
(0.312)\end{array}$ & $\begin{array}{l}20.85 b \\
(0.364)\end{array}$ & $\begin{array}{c}2.48 a b c \\
(0.154)\end{array}$ & $\begin{array}{c}9.99 \\
(0.557)\end{array}$ & $\begin{array}{l}21.77 \mathrm{~b} \\
(0.294)\end{array}$ & $\begin{array}{c}2.63 \\
(0.251)\end{array}$ & $\begin{array}{c}10.10 a b \\
(0.385)\end{array}$ & $\begin{array}{c}22.30 \mathrm{ab} \\
(0.340)\end{array}$ & $\begin{array}{l}2.98 \mathrm{~b} \\
(0.118)\end{array}$ & $\begin{array}{c}10.66 \\
(0.266)\end{array}$ & $\begin{array}{c}22.43 a b \\
(0.485)\end{array}$ \\
\hline $\mathrm{T}_{5}$ & $\begin{array}{c}2.01 \\
(0.226)\end{array}$ & $\begin{array}{l}9.99 \mathrm{ab} \\
(0.312)\end{array}$ & $\begin{array}{c}22.14 a b \\
(0.364)\end{array}$ & $\begin{array}{l}2.07 b c \\
(0.172)\end{array}$ & $\begin{array}{c}9.75 \\
(0.557)\end{array}$ & $\begin{array}{c}22.28 \mathrm{ab} \\
(0.294)\end{array}$ & $\begin{array}{c}2.38 \\
(0.251)\end{array}$ & $\begin{array}{l}10.80 \mathrm{a} \\
(0.385)\end{array}$ & $\begin{array}{l}21.78 b \\
(0.340)\end{array}$ & $\begin{array}{l}3.56 a \\
(0.118)\end{array}$ & $\begin{array}{c}11.08 \\
(0.266)\end{array}$ & $\begin{array}{l}20.96 \mathrm{~b} \\
(0.485)\end{array}$ \\
\hline
\end{tabular}

${ }^{1}$ Means followed by the same letter in the same column do not differ significantly at 0.05 level of probability as shown by the Student-Newman-Keuls (SNK) test.

${ }^{2}$ The number in parentheses below the mean represents the standard deviation

$*, * *$ : significant at 0.05 and 0.01 level of probability, respectively. ns: non-significant at the 0.05 level of probability

${ }^{3} \mathrm{~T}_{1}$ - nutritional and water needs of plants met with $100 \%$ fertigation ( $\mathrm{N}$ and $\mathrm{K}_{2} \mathrm{O}$ ); $\mathrm{T}_{2}-75 \%$ of the volume of TWE associated with $25 \%$ fertigation; $\mathrm{T}_{3}$ - $50 \%$ of the volume of TWE associated with $50 \%$ of fertigation; $T_{4}-25 \%$ of volume of TWE associated with $75 \%$ fertigation; and $T_{5}-100 \%$ of volume of TWE

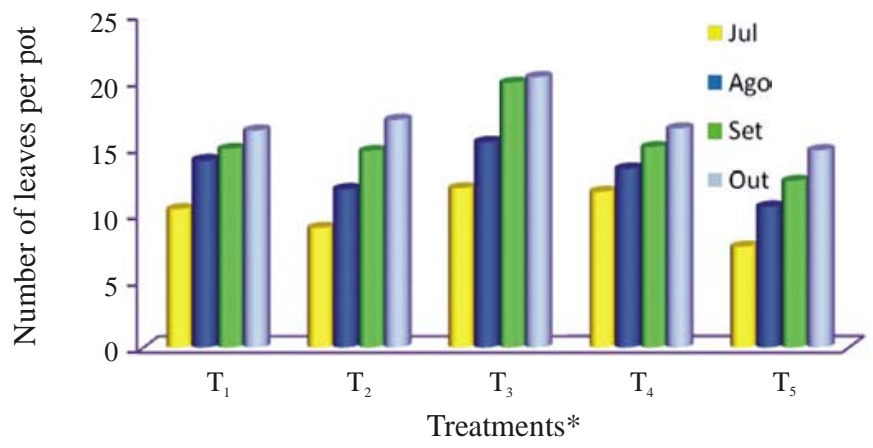

* $\mathrm{T}_{1}$ - nutritional and water needs of plants met with $100 \%$ fertigation ( $\mathrm{N}$ and $\left.\mathrm{K}_{2} \mathrm{O}\right) ; \mathrm{T}_{2}-75 \%$ of the volume of TWE associated with $25 \%$ fertigation; $\mathrm{T}_{3}-50 \%$ of the volume of TWE associated with $50 \%$ of fertigation; $\mathrm{T}_{4}-25 \%$ of volume of TWE associated with $75 \%$ fertigation; and $\mathrm{T}_{5}-100 \%$ of volume of TWE

Figure 1. Mean number of total leaves per plant during the experimentel period under different treatments

wastewater were not sufficient for full development of leaves. On the other hand, in $\mathrm{T}_{3}$ treatment $(50 \%$ TWE associated with $50 \%$ fertigation), the number of leaves during the investigation period was higher in relation to the other treatments, perhaps due to an equilibrium between organic (TWE) and inorganic (fertigation) forms of $\mathrm{N}$.
The number of leaves per plant in the month of August ranged from 15 to 20 in agreement with the results reported by Guiselini (2002), who in protected ambients, observed the mean number of leaves varying from 12.93 and 15.37, and by Mota (2007), who utilising a nutrient solution of electrical conductivity of $2.0 \mathrm{dS} \mathrm{m}^{-1}$, obtained 21 leaves on an average.

\section{Crop quality variables}

The stem height, the capitulum diameter and the stem diameter observed at harvest were evaluated in accordance with the gerbera market requirements. There were rather significant effects of treatments $(\mathrm{p}<0.05)$ only for stem height during the first and second harvest periods (Table 4), and the lowest mean values were obtained in treatments $\mathrm{T}_{4}$ $(37.81 \mathrm{~cm})$ and $\mathrm{T}_{1}(38.41 \mathrm{~cm})$ for July and August, respectively. The observed stem heights were of extra standard (> $40 \mathrm{~cm}$ ) recommended by IBRAFLOR (2000) only in $\mathrm{T}_{2}$ $(46.94 \mathrm{~cm}), \mathrm{T}_{5}(43.33 \mathrm{~cm})$ and $\mathrm{T}_{1}(42.28 \mathrm{~m})$ in the first month (July).

In July and August, the higher means of stem height in relation to other harvesting periods were probably the result of excellent microclimatic conditions (low evapotranspiration

Table 4. Mean stem height ( $\mathrm{AHC}$ ), stem diameter (DHC) and capitulum diameter (DCC) at harvest of the gerbera under different treatments during the experimental period

\begin{tabular}{|c|c|c|c|c|c|c|c|c|c|c|c|c|}
\hline \multirow{3}{*}{$\mathrm{T}^{1}$} & \multicolumn{12}{|c|}{ Mean $^{2}$} \\
\hline & \multicolumn{3}{|c|}{ July } & \multicolumn{3}{|c|}{ August } & \multicolumn{3}{|c|}{ September } & \multicolumn{3}{|c|}{ October } \\
\hline & AHC & DHC & DCC & AHC & DHC & DCC & AHC & DHC & DCC & $A H C$ & DHC & DCC \\
\hline F Test & $* *$ & ns & ns & $* *$ & $* *$ & ns & ns & ns & ns & ns & ns & ns \\
\hline $\mathrm{T}_{1}$ & $42.28 \mathrm{~b}$ & 0.52 & 10.85 & $38.41 \mathrm{~b}$ & $0.56 a$ & 11.77 & 32.27 & 0.54 & 11.33 & 32.05 & 0.55 & 10.54 \\
\hline $\mathrm{T}_{2}$ & $46.94 \mathrm{a}$ & 0.55 & 12.05 & $42.12 \mathrm{a}$ & $0.53 \mathrm{~b}$ & 11.66 & 36.96 & 0.53 & 11.41 & 30.28 & 0.54 & 11.09 \\
\hline $\mathrm{T}_{3}$ & $40.43 b c$ & 0.51 & 10.80 & $39.85 a b$ & $0.54 \mathrm{~b}$ & 11.66 & 32.35 & 0.56 & 11.21 & 29.08 & 0.55 & 10.59 \\
\hline $\mathrm{T}_{4}$ & $37.81 \mathrm{c}$ & 0.53 & 11.19 & $39.77 \mathrm{ab}$ & $0.54 \mathrm{~b}$ & 11.48 & 33.98 & 0.55 & 11.46 & 29.35 & 0.55 & 10.68 \\
\hline $\mathrm{T}_{5}$ & $43.33 b$ & 0.53 & 11.13 & 41.54 a & $0.53 \mathrm{~b}$ & 11.61 & 35.31 & 0.54 & 11.23 & 31.38 & 0.54 & 10.92 \\
\hline
\end{tabular}

${ }_{1} \mathrm{~T} 1$ - nutritional and water needs of plants met with $100 \%$ fertigation ( $\mathrm{N}$ and $\mathrm{K}_{2} \mathrm{O}$ ); $\mathrm{T}_{2}-75 \%$ of the volume of TWE associated with $25 \%$ fertigation; $\mathrm{T}_{3}-50 \%$ of the volume of TWE associated with $50 \%$ of fertigation; $\mathrm{T}_{4}-25 \%$ of volume of TWE associated with $75 \%$ fertigation; and $\mathrm{T}_{5}-100 \%$ of volume of TWE

${ }^{2}$ means in columns followed by the same letter do not differ significantly at a probability level of 0.05 by the Student-Newman-Keuls (SNK) test

$*, * *$ : significant at probability level of 0.05 and 0.01 , respectively. ns: not significant 
and air temperature) within the greenhouse during the initial two months of gerbea cultivation (Table 1). Low temperature and the high relative humidity favor better crop development and better crop quality for commercial purposes. In August, the first changes occurred resulting in significant differences in the variables (Table 4). In this month there were significant differences between the treatments by SNK test. $\mathrm{T}_{1}$ produced higher values of the stem diameter $(0.56 \mathrm{~cm})$, this variable is considered important for the market because a larger diameter provide better sustainability, firmness, resistance and durability of the flowers both during growth and in post harvest period.

No significant results were observed by the $\mathrm{F}$ test for the diameter of flower capitulum in any month. However, the higher values were obtained during the two initial months with 12.05 and $11.77 \mathrm{~cm}$, for $\mathrm{T}_{2}$ and $\mathrm{T}_{1}$, respectively (Table 4). Friedman et al. (2007) did not observe statistical differences for the length of the celosia flower spike when fertigated with effluent. However, 46 and $72 \%$ of cut flowers irrigated with fresh water and effluent were above $60 \mathrm{~cm}$ in the first harvest, while in the second harvest 9.3 and $18.6 \%$ of flowers were longer. Because of this, most flower stems (about 90\%) exhibited better commercial values, no matter what kind of water had been used to irrigate them (effluent or good quality water).

Sakellariou-Makrantonaki et al. (2003) evaluated two growth parameters of ornamental conifers (Juniperus chinensis, Cupressus macrocarpa and Thuja orientalis), demonstrating the first two had longer lengths of lateral shoots although not significant statistically, in spite of the fact that higher values were observed when fresh water was used for irrigation. On the other hand, in the case of Thuja orientalis, the values of stem length were higher when irrigated with wastewater but no significant differences were noted; a fact that was also observed in this study during the final two months as no significant effect was noticed to occur in relation to three growth variables of gerbera. The means of treatments for the stem height were below $40 \mathrm{~cm}$ (Table 4) and considered quite low when compared to those of previous months.

Visual observations of flowers indicated that several plants with shorter flower stems presented, in the final two months, larger diameters as compared to taller plants. During this time, both growth and flower quality began to diminish due to weather variations, especially due to the increase in maximum temperature and low relative humidity of air (Table 1). Even with small flowers, capitulum diameter was still of acceptable quality, because according to INFOAGRO (2007), gerberas may have capitulum diameters ranging from 6.0 to $10.5 \mathrm{~cm}$, and flower stems varying from 30.5 to $46.0 \mathrm{~cm}$.

As seen in Table 4, in the month of September longer stems were verified in $\mathrm{T}_{2}$ and $\mathrm{T}_{5}$ treatments $(36.96 \mathrm{~cm}$ and $35.31 \mathrm{~cm}$, respectively). In October, however, there occurred a decrease in the stem length involving all treatments, the highest values being observed in $T_{1}(32.05 \mathrm{~cm})$ and $T_{5}$ $(31.38 \mathrm{~cm})$. As for diameter of capitulum at harvest $11.41 \mathrm{~cm}$ (September) and $11.09 \mathrm{~cm}$ (October) were observed in $\mathrm{T}_{2}$ treatments.

\section{Number of flowers harvested}

The physiological responses of the crop due to high temperatures and low relative humidity in the greenhouse (Table 1) decreased the number of flowers; since plants under environmental stress have low photosynthetic activity, transpiration, and stomatal conductance and leaf temperature probably higher than the ambient temperature. These characteristics were also observed by Martins \& Gonzalez (1995).

No significant effect of treatments was verified in the number of flowers harvested, neither during the month nor in total (Table 5). Smaller numbers of flowers were harvested under treatment $\mathrm{T}_{5}$ relative to other treatments, particularly in the months of August (3.03 flowers per pot) and September (2.72 flowers per pot) (Table 5). The yield obtained with this treatment $\left(\mathrm{T}_{5}\right)$ was still slightly higher than that reported by BioLab Tecnologia Vegetal. (25.6 flowers per plant per year), and observed by Medeiros et al. (2007) who reported on an average 4.4 flowers per plant during a period of 150 days with the same variety. The results of this trial are very promising, considering that, when wastewater is used for irrigation, there is no need to acquire fertilizers and this reduces production costs substantially. In plants fertigated with $100 \%$ chemical fertilizer with additional costs, the number of flowers produced was only $6.1 \%$ higher in relation to plants treated with $100 \%$ TWE (Table 5).

The fertilizing and nutritional potential of treated effluents points towards the application of these effluents in the agricultural activities with the economy of fertilizers as stated by Bastos (1999). In treatment $\mathrm{T}_{4}$, there were about 14.1 flowers per plant, which represents a total of 42.3 flowers per

Table 5. Mean number of flowers harvested per plant under different treatments during the experimental period

\begin{tabular}{cccccc}
\hline Treatments $^{2}$ & \multicolumn{5}{c}{ Number of flowers per plant ${ }^{1}$} \\
\cline { 2 - 6 } & July & August & September & October & Total \\
$\mathrm{F} \mathrm{Test}$ & $\mathrm{ns}$ & $\mathrm{ns}$ & $\mathrm{ns}$ & $\mathrm{ns}$ & $\mathrm{ns}$ \\
$\mathrm{T}_{1}$ & $1.63 \pm 0,146$ & $3.84 \pm 0,159$ & $3.24 \pm 0,107$ & $2.19 \pm 0.266$ & $10.90 \pm 1.993$ \\
$\mathrm{~T}_{2}$ & $1.00 \pm 0.178$ & $4.54 \pm 0.159$ & $3.35 \pm 0.107$ & $1.85 \pm 0.230$ & $10.74 \pm 2.102$ \\
$\mathrm{~T}_{3}$ & $1.90 \pm 0.146$ & $3.50 \pm 0.159$ & $3.53 \pm 0.107$ & $1.44 \pm 0.230$ & $10.37 \pm 1.832$ \\
$\mathrm{~T}_{4}$ & $1.32 \pm 0.113$ & $5.71 \pm 0.159$ & $4.54 \pm 0.107$ & $2.53 \pm 0.206$ & $14.10 \pm 1.536$ \\
$\mathrm{~T}_{5}$ & $1.93 \pm 0.113$ & $3.03 \pm 0.178$ & $2.72 \pm 0.120$ & $2.54 \pm 0.230$ & $10.22 \pm 1.706$ \\
\hline
\end{tabular}

\footnotetext{
${ }^{1}$ The number followed by mean after ' \pm ' represent the mean standard deviation

${ }^{2} \mathrm{~T}_{1}$ - nutritional and water needs of plants met with $100 \%$ fertigation ( $\mathrm{N}$ and $\mathrm{K}_{2} \mathrm{O}$ ) $; \mathrm{T}_{2}-75 \%$ of the volume of TWE associated with $25 \%$ fertigation; $\mathrm{T}_{3}-50 \%$ of the volume of TWE associated with $50 \%$ of fertigation; $\mathrm{T}_{4}-25 \%$ of volume of TWE associated with $75 \%$ fertigation; and $\mathrm{T}_{5}-100 \%$ of volume of TWE
} 
plant per year; production considered as excellent, since, according to INFOAGRO (2007) gerbera yields vary substantially, obtaining on an average of 25 flowers plant ${ }^{-1}$ in the second year and 24 flowers plant ${ }^{-1}$ in the third year. It is worth while to mention that the seedlings used in the present study were obtained from plants one and half years old.

On the whole, the study presented satisfactory results, showing the feasibility of irrigating gerbera with domestic effluents treated in the region during the period of favorable temperatures. According to Mota (2007), soil temperature affects the interval between appearance of sucessive flower buds, the final length of plant stem, and the rate of stem growth during the last stages of plant development. Therefore, it is recommended that further studies should be conducted to find out long term effects. These challenges point towards the necessity of investigating, under protected ambientes, losses in yield, the effects of humidification and natural ventilation in reducing temperature and preserving flower quality during the critical periods of the year.

\section{CONCLUSIONS}

1. Treated wastewater effluents from domestic sewage can be used for irrigating gerberas under protected ambinet conditions without loss of quality and growth - with and without mineral supplementation.

2. The growth and leaf development of gerberas were favored under the treatment containing $50 \%$ of mineral fertilizer associated with $50 \%$ treated wastewater effluent.

3. In terms of flower quality, treatment with $75 \%$ of treated wastewater effluent associated with $25 \%$ of mineral fertigation resulted in extra quality flowers in July and August; whereas, in the months of September and October, all treatments produced flowers of only acceptable commercial quality.

4. No significant effect was observed for different combination of treated wastewater effluent with mineral fertigation relative to the number of flowers harvested, neither during the specific month nor in total.

\section{ACKNOWLEDGMENTS}

The authors wish to express their gratitude to CTHIDRO/CNPq for the scholarship granted to first author; to the Companhia de Águas e Esgotos do Piauí S.A, for providing the treated domestic effluents; to NAANDAN, for providing the irrigation equipment; and to the Fundação de Amparo à Pesquisa do Piauí (FAPEPI), for sponsoring this research project.

\section{LITERATURE CITED}

Andrade Neto, C. O. de; Melo, H. N. S.; Abujamra, R. C. P. Utilização de água residuária tratada em sistemas hidropônicos. In: Workshop Uso e Reúso de Águas de Qualidade Inferior, 2005, Uso e reúso de águas: Realidades e perspectivas. Campina Grande. Anais... Campina Grande: UFCG; UEPB, 2005, cap. 8. CD-Rom.

Bastos, R. K. X. Fertirrigação com águas residuárias. In: Folegatti, M. V. (coord.). Fertirrigação: Cítrus, flores, hortaliças. Guaíba: Agropecuária, 1999. 279p.

Bazza, M. Wastewater reuse in the near east region: Experience and issues. In: IWA Regional Symposium on Water Recycling in the Mediterranean Region, 2002, IRAKLIO. Proceedings.... London: International Water Association, 2002. 326p.

Bernstein, N.; Tal, A.B.; Friedman, H.; Snir, P.; Rot, I.; Chazan, A.; Ioffe, M. Application of treated wastewater for cultivation of roses (Rosa hybrida) in soil-less culture. Scientia Horticulturae, v.108, p.185-193, 2006.

Capra, A.; Scicolone, B. Recycling of poor quality urban wastewater by drip irrigation systems. Journal of Cleaner Production, v.15, p.1529-1534, 2007.

Carr, R. M.; Blumenthal, V. J.; Mara, D. D. Guidelines for the safe use of wastewater in agriculture: Revisiting WHO guidelines. Water Science and Technology, v.50, n.2, p.31-38, 2004.

Cerqueira, L. L. Aplicação de efluente de estação de tratamento de esgoto doméstico na irrigação de plantas ornamentais. Cruz das Almas: CCAA/UFBA, 2006. 65p. Dissertação Mestrado

Darwish, M. R.; El Awar, F. A.; Sharara, M.; Hamdar, B. Economic-environmental approach for optimum wastewater utilization in irrigation: A case study in Lebanon. Applied Engineering in Agriculture, v.15, n.1, p.41-48, 1999.

EMBRAPA - Empresa Brasileira de Pesquisa Agropecuária. Manual de métodos de análise de solo. 2.ed. rev. atual. Rio de Janeiro: Embrapa, CNPS, 1997. 212p. Documentos, 1

Friedman, H.; Bernstein, N.; Bruner, M.; Rota, I.; Ben-Noon, Z.; Zuriel, A.; Zuriel, R.; Finkelstein, S.; Umiel, N.; Hagiladi, A. Application of secondary-treated effluents for cultivation of sunflower (Helianthus annuus L.) and celosia (Celosia argentea L.) as cut flowers. Scientia Horticulturae, v.115, n.1, p.62-69, 2007.

Guiselini, C. Microclima na produção de gérbera em ambiente protegido com diferentes tipos de cobertura. Piracicaba: ESALQ/USP, 2002. 53p.

IBRAFLOR - Instituto Brasileiro de Floricultura. Padrão IBRAFLOR de qualidade, Campinas: IBRAFLOR, 2000. 87p.

INFOAGRO. El cultivo de la gerbera. <http://www.infoagro.com/ flores/flores/gerbera.htm>. 12 Abr. 2007.

Janosova, B.; Miklankova, J.; Hlavinek, P.; Wintgens, T. Drivers for wastewater reuse: Regional analysis in the Czech Republic. Desalination, v.187, n.1/3, p.103-114, 2006.

Keller, J.; Bliesner, R. D. Sprinkle and trickle irrigation. New York: van Nostrand Reinhold, 1990. 652p. 
Lima, I. M. M. F.; Oliveira, A. L.; Fé, C. A. M. A cidade que queremos: diagnósticos e cenários do meio ambiente. In: Piauí. Prefeitura Municipal de Teresina. Teresina agenda 2015: Plano de desenvolvimento sustentável. Teresina: PMT, 2002.

Martins, S. R.; Gonzalez, J. F. Evapotranspiração e respostas fisiológicas do feijão-vagem cultivado em substrato em estufa com sistema de ventilação/calefação. Revista Brasileira de Agrometeorologia, v.3, n.1, p.31-37, 1995.

Medeiros, S. de S.; Soares, F. A. L.; Gheyi, H. R.; Fernandes, P. D. Uso de água residuária de origem urbana no cultivo de gérberas: Efeitos nos componentes de produção. Engenharia Agrícola, v.27, n.2, p.569-578, 2007.

Mota, P. R. D. Aplicação via fertirrigação de soluções com diferentes condutividades elétricas para produção de gérbera (Gerbera jamesonii L.) sob ambiente protegido. Botucatu: FCA/ UNESP, 2007. 96p. Tese Doutorado

Mutengu, S.; Hoko, Z.; Makoni, F. S. An assessment of the public health hazard of wastewater reuse for crop production: A case of Bulawayo city, Zimbabwe. Physics and Chemistry of the Earth, v.32, n.15/18, p.1195-1203, 2007.
Papadopoulos, I.; Chimonidou, D.; Savides, S; Polycarpo, P. Optimization of irrigation with treated wastewater on flower cultivations. In: Workshop Non-Conventional Water Use, 2004, Cairo. http://wasamed.iamb.it/allegati_int/18/ cyprus1.pdf. 02 fev. 2004.

Sakellariou-Makrantonaki, M.; Tentas, I; A. Koliou, A. Kalfountzos, D. and Vyrlas, P. Irrigation of ornamental shrubs with treated municipal wastewater. In: International Conference on Environmental Science and Technology, 8, 2003, Lemnos. 2003. Pr oceedings... Lemnos: Global Network for Environmental Science and Technology, 2003. 8p.

SAS Institute. SAS/STAT user's guide, version 6. Cary: SAS Institute, 1989. v.1, 943p.

SEBRAE - Serviço Brasileiro de Apoio a Micro e Pequena Empresa - SEBRAE-PI. Floricultura tropical em debate. (18/11/ 05). http://sebraepi.interjornal.com.br/noticia.kmf? noticia $=3879593 \&$ canal $=250.23$ Mar. 2008.

Toze, S. Reuse of effluent: Water-benefits and risks. Agricultural Water Management, v.80, n.1/3, p.147-159, 2006. 